\title{
Variations in the density and variety of intertidal epilithic microflora
}

\author{
John H. MacLulich \\ Zoology Building, AO8, School of Biological Sciences, University of Sydney, N.S.W. 2006, Australia
}

\begin{abstract}
In order to investigate seasonal changes in the density and variety of the microfloral assemblage, samples were collected from an intertidal rock platform near Sydney, Australia, by brushing the rock surface with a toothbrush. A large number of samples was obtained from the natural sandstone substratum at different levels on the shore and at different sites. The assemblage was dominated by a blue-green alga, Anacystis sp., a situation not previously described in any similar system. Also present were diatoms and various red, green and brown algal sporelings. Density of cells in the assemblage was greatest in winter, whereas variety was greatest in summer Both density and variety were greater lower on the shore and at more wave-exposed sites. These patterns differ from those reported by other studies perhaps because the site is different in terms of its weather and its community of grazing gastropods.
\end{abstract}

\section{INTRODUCTION}

The study of patterns of distribution, diversity and abundance of plants and animals forms the basis of a great many ecological investigations. In rocky intertidal habitats, many studies have been concerned with the patterns of vertical and horizontal distribution of species and the seasonal changes in these patterns, especially in relation to physical factors. Although abundant documentation of such patterns exists for macroscopic forms (e.g. Dakin et al. 1948, Lewis 1964, Dakin 1969, Dayton 1971, Stephenson \& Stephenson 1972) including a study made at Green Point, near Sydney, Australia, (the site of the present investigation) by Underwood (1981), little is understood about any aspect of the ecology of microscopic forms, especially the microflora. Some authors (Ghazzawi 1933, Aleem 1949, 1950, Castenholz 1963, Hopkins 1964a, b, McIntire \& Overton 1971) have documented the distribution of diatoms in various parts of the world. On a smaller scale, variations in the distribution of diatoms have been related to variations in the topography of the substratum, light intensity and duration, emersion time, salinity and desiccation (Castenholz 1963, 1967. McIntire \& Wulff 1969, Wulff \& McIntire 1972) and appear, therefore, to be complex. Several authors have made observations about diversity, abundance and species interactions for freshwater diatoms (Patrick et al. 1954, Patrick 1948, 1964, 1968, 1972, Hoagland et al. 1982) and seasonal patterns have been observed for planktonic forms (Mare 1940, Jeffrey \& Carpenter 1974).

In comparison, information about seasonal patterns in intertidal assemblages is scarce (Aleem 1950, Castenholz 1961a, Hopkins 1964b). With the exception of a preliminary study by Dunkerley (1979), no information of this nature is documented for epilithic microalgae on coastal rock platforms in eastern Australia. In other studies on shores in New South Wales, competition for microalgal food resources is important in the dynamics and structure of mid-shore communities (Underwood 1976). Also, grazers of microalgae have major effects on the structure of macroalgal communities (Underwood 1980, Underwood \& Jernakoff 1981, 1984j. Despite this, very little is known about the microalgal food resource. A monthly sampling program was undertaken in order to provide information about the patterns of density and diversity of the microflora. Related studies of microalgae by other workers (references above) have studied only diatoms, which are numerically dominant, and have studied assemblages on artificial substrata. In the present study, samples were collected from the natural sandstone substratum and all taxa were considered. 


\section{MATERIALS AND METHODS}

Site. The study site encompassed the entire length of the rock platform at Green Point, $35 \mathrm{~km}$ north of Sydney, N.S.W., Australia. This platform was described in detail by Underwood (1981)

Three, usually distinct, tidal levels could be identified at all sites along the Green Point rock platform. These were: (1) low-level - characterised by the limpets Cellana tramoserica (Sowerby), Patelloida latistrigata Angas. and Siphonaria sp., and a patchy cover of macroalgae; (2) middle-level - characterised by the periwinkles Austrocochlea constricta (Lamarck), Bembicium nanum (Lamarck) and Nerita atramentosa Reeve, a patchy cover of barnacles and no macroalgae; (3) high-level - characterised by the periwinkles Littorina unifasciata Gray and Nodilittorina pyramidalis (Quoy \& Gaimard).

Sampling. Regular samples were collected by the 'toothbrush' method described by MacLulich (1986). Five such samples were taken from each of 3 levels on each of 5 vertical transects in the space of a single low tide. The 5 transects were approximately $100 \mathrm{~m}$ apart, the northernmost (Transect 1) being at the headland of Green Point, where exposure to wave action is greatest (Underwood 1981). At each level of each transect, an area approximately $1 \mathrm{~m}$ (high) $\times 5 \mathrm{~m}$ (wide) was defined, from which all subsequent samples were taken.

Beginning in August 1980, samples were collected at approximately $4 \mathrm{wk}$ intervals over the following $16 \mathrm{mo}$, until November 1981. Five randomly placed $5 \times 5 \mathrm{~cm}$ (approx.) squares were marked within the previously defined boundaries of each sample area, avoiding areas covered by macroalgae and areas that had previously been sampled. Each square was sampled by brushing the rock surface with a toothbrush, and the exact area of rock from which the samples were collected was measured. The samples (preserved in $10 \%$ formalin/seawater) were stored in the laboratory until, in May and November 1981 and January 1982, the accumulated samples were assayed: the numbers and types of all cells were recorded (using the light microscope, as described in MacLulich 1986) and estimates of the density and variety of the microalgal assemblage were calculated. The variety of cells was measured as the number of species in a random subsample, and is more correctly an estimate of species richness.

Air temperature, seawater temperature, rainfal.I, wind strength, sunshine hours and degree of swell (which were all obtained from the N.S.W. Bureau of Meteorology records for the nearest meteorological station to Green Point) were also recorded. The density of grazers in each sampling area was estimated by counting all individuals found in 5 randomly placed $50 \times 50$ cm quadrats (see Underwood 1981 for details of this procedure).

\section{RESULTS}

\section{Density}

At every transect, the density of cells was greatest in winter and least in summer (Fig. 1, Table 1). Maximum density was $11.3 \times 10^{5}$ cells $\mathrm{cm}^{-2}$ and minimum density was $3.3 \times 10^{5}$ cells $\mathrm{cm}^{-2}$. Seasonal differences varied according to the degree of exposure to wave action, being greatest where this exposure was maximum (Transect 1) and least where exposure was minimum (Transect 5). The overall density of cells was also generally greater at exposed areas (Transect 1) than at protected areas (Transect 5); intermediate areas (Transects 2, 3 and 4) having intermediate densities (S.N.K. tests; Table 1). Tidal height also affected density: at any given transect, the density of cells was usually greatest at the low level and least at the high level. This is probably related to period of emersion, but may also be a result of differing degrees of grazing activity. Differences in density among transects, among levels and among times were shown to be statistically significant (analysis of variance and S.N.K. tests; Table 1). Being on a natural rock substratum, the microfloral assemblage was extremely patchy: the residual variance was the greatest source of variation (Table 1).

Three major groupings of the microflora were considered. These were: (1) the blue-green alga Anacystis

Table 1. Three-factor analysis of variance of seasonal changes in density of microflora, at each level of each transect. Variances were homogeneous: Cochran's test, $p>0.05$. Results of Student-Newmann-Keuls tests of the means for each transect and each level are given below the table. In this and subsequent tables: ns, mon-significant, $p>0.05$; 'significant, $p<0.05 ; \cdots p<0.01$

\begin{tabular}{|c|c|c|c|}
\hline $\begin{array}{l}\text { Source of } \\
\text { variance }\end{array}$ & d.f. & Mean square & F ratio \\
\hline Transect (Tr) & 4 & 254.8 & $46.4^{\cdots}$ \\
\hline Level (L) & 2 & 262.3 & $47.7 \cdots$ \\
\hline Time (Ti) & 15 & 53.3 & $9.7^{\cdots}$ \\
\hline $\operatorname{Tr} \times \mathrm{L}$ & 8 & 9.5 & $1.8 \mathrm{~ns}$ \\
\hline $\operatorname{Tr} \times \operatorname{Ti}$ & 60 & 4.9 & $0.9 \mathrm{~ns}$ \\
\hline $\mathrm{L} \times \mathrm{Ti}$ & 30 & 3.1 & $0.6 \mathrm{~ns}$ \\
\hline $\mathrm{Tr} \times \mathrm{L} \times \mathrm{Ti}$ & 120 & 1.9 & $0.3 \mathrm{~ns}$ \\
\hline Resicual & 960 & 5.5 & - \\
\hline \multicolumn{4}{|c|}{$\begin{array}{l}\text { S.N.K. tests: } \\
\text { (a) Overall means for each transect: } \operatorname{Tr} 1>\operatorname{Tr} 2>\operatorname{Tr} 3>\operatorname{Tr} 4 \\
\qquad=\operatorname{Tr} 5 \\
\text { (b) Overall means tor each level: Low }=\text { Middle }>\text { High }\end{array}$} \\
\hline
\end{tabular}


sp.; (2) diatoms; and (3) spores and sporelings (Fig. 2). Because the density and variety (and the seasonal changes in these 2 variables) were all greatest at Transect 1 , only the data from Transect 1 are presented: at all other transects, the variations were very similar to those at Transect 1, the only obvious difference being a greater total density at Transect 1 than at Transects 2 to 5. Anacystis was common at all levels of all transects at all times of the year, but appeared to be at greater densities at the low levels and during winter (Fig. 2A). This filamentous blue-green alga was found in num-
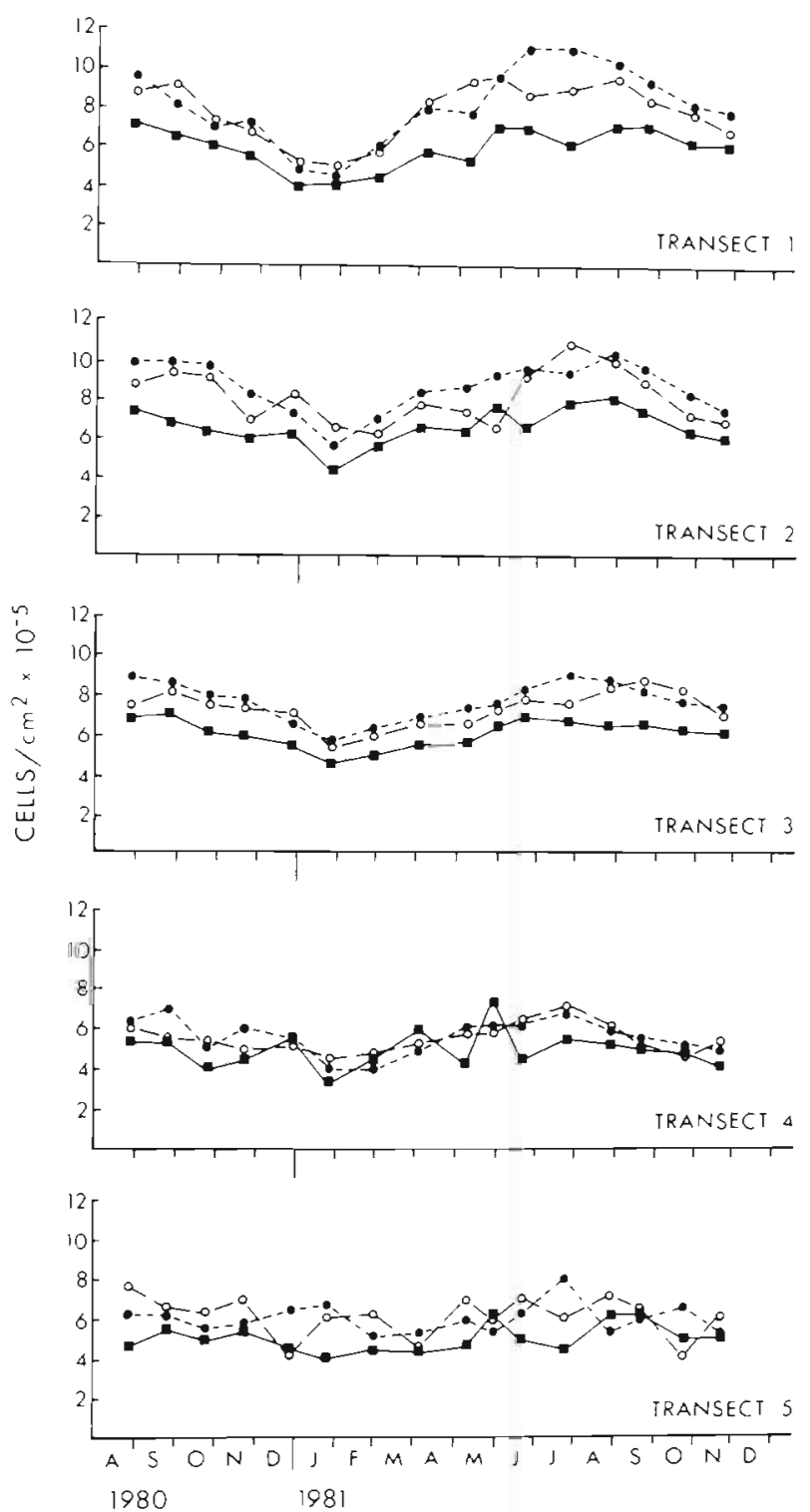

Fig. 1 Changes in density of microflora, over time, at each level of each transect. ( $)$ High level; (a) middle level; (-) low level. Pooled SE for all means is 1.05 cells $/ \mathrm{cm}^{2} \times 10^{-5}$ bers from 2.3 to $8.3 \times 10^{5}$ cells $\mathrm{cm}^{-2}$, which represented 66 to $79 \%$ of the total density of all cells. Diatoms increased in number in October-November (late spring) and possibly again in May-June (late autumn). They were slightly more abundant at the low levels (Fig. 2B). Spores were more common at the low levels and were in greater numbers during winter (Fig, 2C). The seasonal variations in density of these 3 groupings accounted for the total seasonal changes described above. No seasonal patterns were observed for the remaining taxa (Fig. 2D).
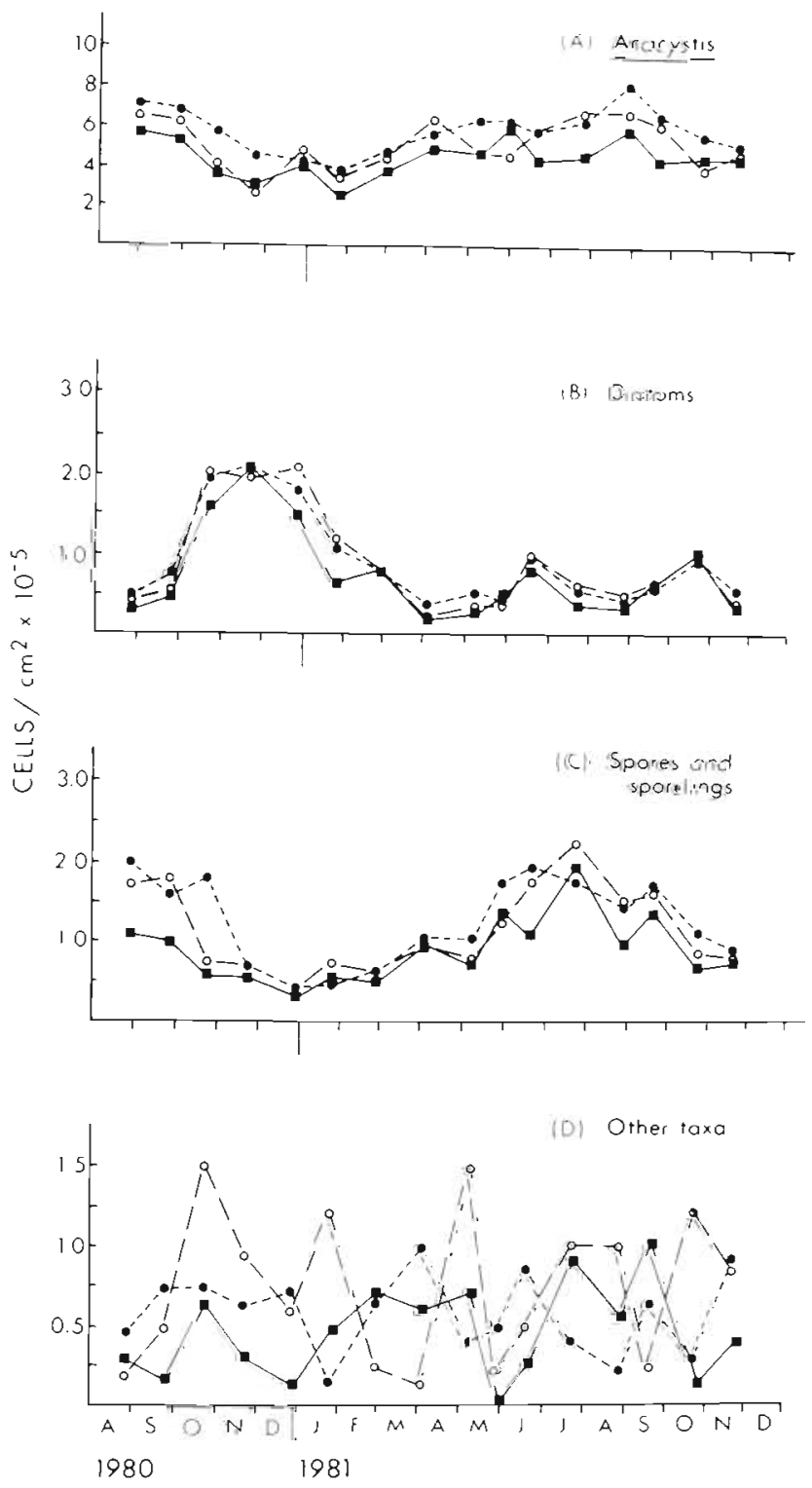

Fig. 2. Changes in density of the major components of the microflora, over time, at each level of Transect 1. (ロ) High level; (O) middle level; ( ) low level. Pooled SEs for all means are (A) 1.12 ; (B) 0.83 ; (C) 0.74 ; (D) $1.21 \mathrm{cells} / \mathrm{cm}^{2} \times 10^{-5}$ 


\section{Variety}

Variety was significantly greater at the low levels on the shore, reaching a maximum in summer (Fig. 3). It also varied significantly according to position on the shore, being greater at the most exposed transects (Transects 1 to 4) and less at the most protected transect (Transect 5) (Table 2). Again, the residual variance accounted for the greatest part of the total variance (see Table 2), reflecting the patchiness of the assemblages that were sampled.

A total of 28 taxa were identified in the 1200 samples collected in 16 mo (Table 3). A further 11 taxa were unidentified: they were found in less than $5 \%$ of the 1200 samples. The more common taxa were grouped on the basis of the season(s) and level(s) in which they were most abundant (Table 4). Anacystis sp. was

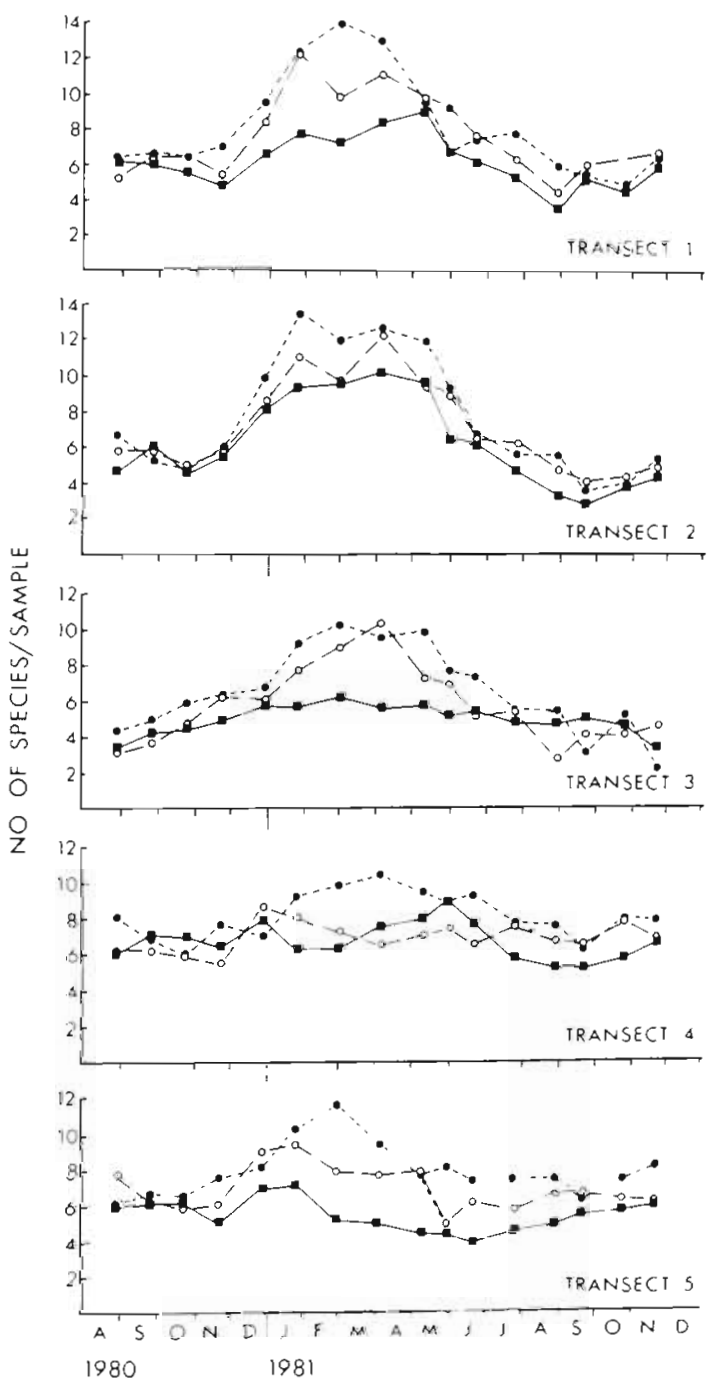

Fig. 3. Changes in variety of the microflora, over time, at each level of each transect. (ロ) High level; (c) middle level; (-) Iow level. Pooled SE for all means is 1.74 species/sample extremely common at all levels of all transects at all times of the year, often accounting for over $70 \%$ of the microfloral cells.

Table 2. Three-factor analysis of variance of seasonal changes in variety of the microflora, at each level of each transect. Variances were homogeneous: Cochran's test, $p>0.05$ Results of Student-Newmann-Keuls tests of the means for each transect and each level are given below the table.

\begin{tabular}{|c|c|c|c|}
\hline $\begin{array}{l}\text { Source of } \\
\text { variance }\end{array}$ & d.f. & Mean square & F ratio \\
\hline Transect (Tr) & 4 & 97.8 & $6.4^{\cdots}$ \\
\hline Level (L) & 2 & 346.0 & $22.8^{*}$ \\
\hline Time (Ti) & 15 & 173.0 & $11.4^{\cdots}$ \\
\hline $\operatorname{Tr} \times \mathrm{L}$ & 8 & 6.2 & $0.4 \mathrm{~ns}$ \\
\hline $\operatorname{Tr} \times \operatorname{Ti}$ & 60 & 16.7 & $1.1 \mathrm{~ns}$ \\
\hline $\mathrm{L} \times \mathrm{Ti}$ & 30 & 12.2 & $0.8 \mathrm{~ns}$ \\
\hline $\operatorname{Tr} \times \mathrm{L} \times \mathrm{Ti}$ & 120 & 3.2 & $0.2 \mathrm{~ns}$ \\
\hline Residual & 960 & 15.2 & - \\
\hline \multicolumn{4}{|c|}{ 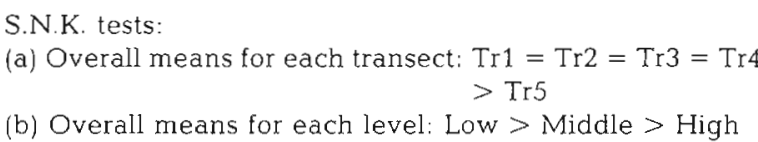 } \\
\hline
\end{tabular}

Table 3. Common taxa of the microfloral assemblage. Identification to species level was not atternpted

\begin{tabular}{|ll|}
\hline Group & Taxon \\
\hline Blue-green algae & Anacystis \\
& Chroococcus \\
& Lyngbya \\
& Oscillatoria \\
Green algae & Chaetomorpha \\
& Chlorella \\
& Enteromorpha \\
Scenedesmus \\
Ulva \\
Ralfsia \\
Red algae & Polysiphonia \\
Diatoms & Achnanthes \\
& Chaetoceros \\
& Cocconeis sp. 1 \\
Cocconeis sp. 2 \\
Cocconeis sp. 3 \\
Coscinodiscus sp. 1 \\
Coscinodiscus sp. 2 \\
Fragilaria \\
Licmophora \\
Melosira \\
Navicula sp. 1 \\
Navicula sp. 2 \\
Navicula sp. 3 \\
Nitzschia \\
Pinnularia \\
Stauroneis \\
Synedra \\
\\
\end{tabular}


Table 4. Categorization of the microflora

\begin{tabular}{|c|c|c|c|}
\hline Abundance & $\begin{array}{c}\text { Season of } \\
\text { maximum } \\
\text { density }\end{array}$ & $\begin{array}{l}\text { Level of } \\
\text { maximum } \\
\text { density }\end{array}$ & Taxon \\
\hline $\begin{array}{l}\text { Extremely } \\
\text { common }\end{array}$ & All year & All levels & Anacystis \\
\hline $\begin{array}{l}\text { Very } \\
\text { common }\end{array}$ & $\begin{array}{l}\text { All year } \\
\text { Spring } \\
\text { Winter }\end{array}$ & $\begin{array}{l}\text { All levels } \\
\text { All levels } \\
\text { All levels }\end{array}$ & $\begin{array}{l}\text { Bacteria } \\
\text { Oscillatoria } \\
\text { Lyngbya }\end{array}$ \\
\hline Common & $\begin{array}{l}\text { All year } \\
\text { Spring }\end{array}$ & $\begin{array}{l}\text { Upper } \\
\text { All levels }\end{array}$ & $\begin{array}{l}\text { Lichens, fungi } \\
\text { Chroococcus } \\
\text { Coscinodiscus sp. } 2 \\
\text { Cocconeis sp. 1, } 3 \\
\text { Chlorella } \\
\text { Polysiphonia } \\
\text { Enteromorpha } \\
\text { Ralfsia } \\
\text { Ulva }\end{array}$ \\
\hline Scarce & $\begin{array}{l}\text { Spring } \\
\text { Winter }\end{array}$ & All levels & $\begin{array}{l}\text { Achnanthes } \\
\text { Licmophora } \\
\text { Navicula sp. 1, } 3 \\
\text { Nitzschia } \\
\text { Chaetomorpha } \\
\text { Scenedesmus }\end{array}$ \\
\hline Rare & Various & Various & $\begin{array}{l}\text { Cocconeis sp. } 2 \\
\text { Coscinodiscus sp. } 1 \\
\text { Fragilaria } \\
\text { Chaetoceros } \\
\text { Melosira } \\
\text { Synedra } \\
\text { Stauroneis } \\
\text { Pinnularia } \\
\text { Navicula sp. } 2\end{array}$ \\
\hline
\end{tabular}

Two groups, diatoms and spores/sporelings, accounted for the greatest part of the seasonal changes in variety (Fig. 4). The number of species of diatoms increased dramatically in March-April (late summer) and fell to very small numbers during winter. Little difference was observed among levels (Fig. 4A). The variety of spores and sporelings reached a maximum in October-November (late spring) of 1980, fell, and remained fairly constant over the remainder of the sampling period. This increase was only observed at the low levels: the number of species of spores at the middle and high levels was constant, and low, during the entire sampling period (Fig. 4B). No seasonal changes in variety were evident for the remaining taxa, which included multicellular and blue-green algae (Fig. 4C).

Seasonal effects of air and seawater temperature can be altered by unrelated variations in many other physical factors which may act to enhance or negate their overall effects. Air temperature and seawater temperature both peaked during summer (Fig. 5). Rainfall, sunshine hours, wind strength and degree of swell showed no distinct seasonal trends, but are likely to have a significant effect on the microfloral assemblages in that they can modify the effects of desiccation and emersion.

The density of grazing gastropods at Transect 1 was much larger at the high level than at the low level (Table 5), because of the predominance of one species, Littorina unifasciata. All other species were found only at the middle and low levels. Recruitment and the subsequent increase in density of $L$. unifasciata may have occurred in summer. The density of Austrocochlea constricta at the low level increased significantly in spring, whereas the density of Bembicium nanum at the low level increased in summer. Cellana tramoserica, however, showed no significant seasonal variations in density. Similar seasonal and spatial variations were observed for all these species at all other transects.
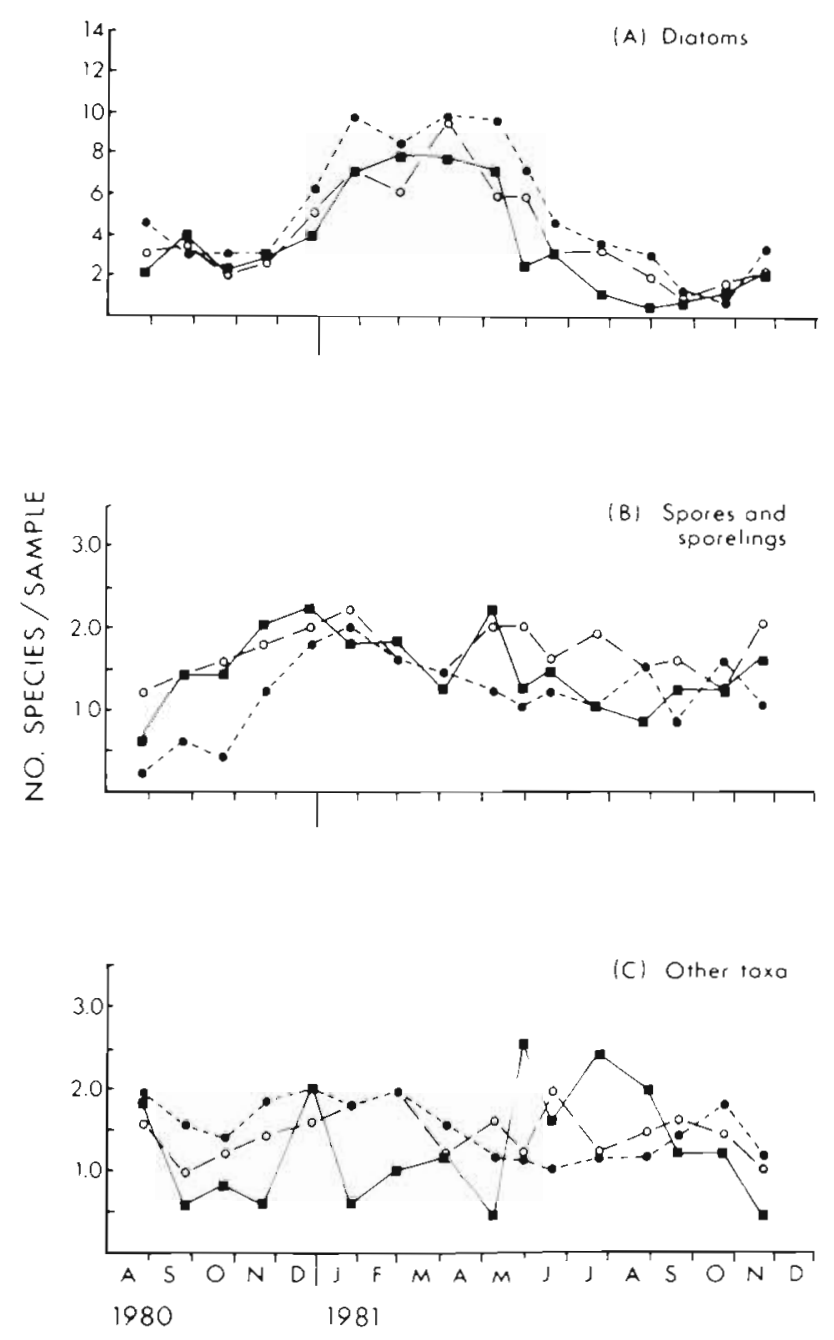

Fig. 4. Changes in variety of the major components of the

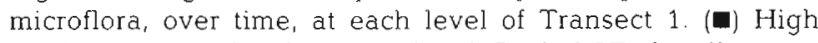
level; (O) middle level; ( low level. Pooled SEs for all means are (A) $1.43 ;$ (B) 0.97 ; (C) 1.06 species/sample 
At all levels, multiple correlations revealed that both density and variety were strongly correlated with air temperature and with seawater temperature: with increasing temperature, density decreased and variety increased (Table 6). Wind strength and variety were strongly correlated (at all levels): as wind strength increased, variety decreased. Density of grazers and variety of the microflora were weakly correlated: with increasing density of grazers, variety increased, especially at the upper level. Period of exposure to sunlight and density of the microflora were also weakly correlated: with increasing period of sunlight, the density of cells increased. Of course, causal relations are not explained by these correlations.

\section{DISCUSSION}

The microfloral assemblage at Green Point is composed of the blue-green alga Anacystis sp., several species of diatoms and spores of green, red and brown algae. This composition appears to be unusual: bluegreen algae have not previously been reported as major constituents of intertidal assemblages.

As is the case for many macroscopic organisms in intertidal systems, the distribution of the microflora was very patchy. Most previously published investigations of intertidal microflora have stressed this observation (Castenholz 1961a, 1963, Nicotri 1974, 1977) and these workers have resorted to sampling from artificial substrata in order to minimise the 'noise' in their systems. In the present study, the natural substratum was sampled and hence the patchiness was, as expected, very large. The large number of samples that was studied, however, made it possible to detect variations of the assemblage (in time and space), despite this problem. The spatial and temporal variations differ from those of assemblages previously reported.

The variations in density and variety of the microfloral assemblage at Green Point can be summarised in 4 points: (1) Both density and variety were greatest where exposure to wave action was greatest. (2) Both density and variety were greatest at low levels on the shore. (3) The microflora density was greatest during winter. (4) The variety of the assemblage was greatest during summer.

\section{Spatial variations}

Underwood (1981) reported that the high density and variety at the most wave-exposed transect correlates inversely with the density of macroscopic animals at Green Point, and that greater densities of grazers and increased diversity of grazers and sessile animals were
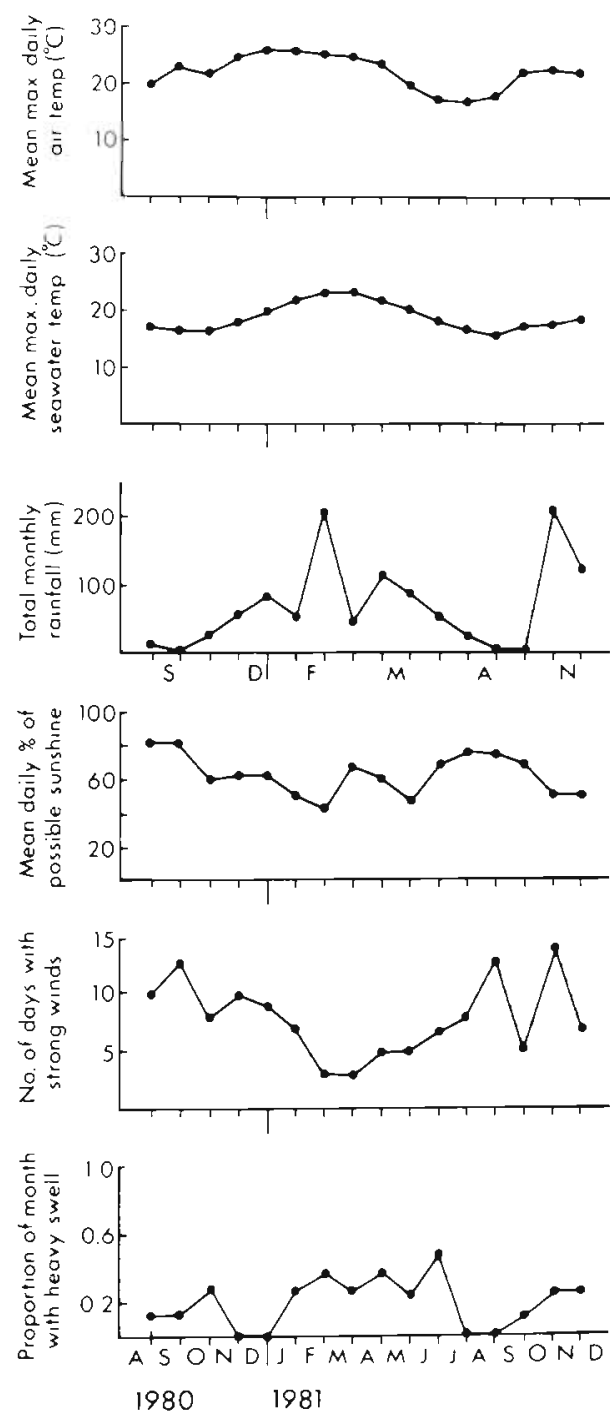

Fig. 5. Seasonal changes in aspects of the weather during the period of the study (August 1980 to November 1981)

evident at the protected end of the shore. This is not unexpected, but explanations other than grazing pressure are possible: microscopic organisms more easily survive splash and surge than macroscopic organisms. Firmly attached, endolithic or parenchymatous forms will not experience the shearing force of the waves because they are in the near-surface laminar flow region and because the velocity of flow in the boundary layer is less. Also, increased wave action at exposed areas provides more nutrients and greater gas exchange, as well as reducing the period of emersion. desiccation and heating Castenholz (1963) has reported that many species of diatoms have very low tolerances to desiccation, high temperature, high light intensity and U.V. radiation, and can withstand only short periods of exposure to air 
Table 5. Density of grazing gastropods at Transect 1 Data are presented as the mean number in 15 quadrats of $50 \times 50 \mathrm{~cm}(5$ sampled 3 times in each season). Pooled SE for all means is 7.1 grazers quadrat $^{-1}$

\begin{tabular}{|c|c|c|c|c|c|c|}
\hline Height on shore & Species & $\begin{array}{c}\text { Spring } \\
1980\end{array}$ & $\begin{array}{l}\text { Summer } \\
1980 / 81\end{array}$ & $\begin{array}{c}\text { Autumn } \\
1981\end{array}$ & $\begin{array}{c}\text { Winter } \\
1981\end{array}$ & $\begin{array}{c}\text { Spring } \\
1981\end{array}$ \\
\hline High level & Littorina unifasciata & 308.6 & 443.7 & 400.3 & 307.4 & 212.2 \\
\hline Middle level & $\begin{array}{l}\text { Littorina unifasciata } \\
\text { Austrocochlea constricta } \\
\text { Bembicium nanum } \\
\text { Cellana tramoserica }\end{array}$ & $\begin{array}{r}3.3 \\
13.7 \\
10.3 \\
6.3\end{array}$ & $\begin{array}{l}20.7 \\
16.3 \\
10.0 \\
10.0\end{array}$ & $\begin{array}{r}0.3 \\
12.0 \\
16.3 \\
10.0\end{array}$ & $\begin{array}{r}1.7 \\
14.3 \\
11.3 \\
9.3\end{array}$ & $\begin{array}{l}1.3 \\
7.3 \\
9.3 \\
6.7\end{array}$ \\
\hline Low level & $\begin{array}{l}\text { Austrocochlea constricta } \\
\text { Bembicium nanum } \\
\text { Cellana tramoserica }\end{array}$ & $\begin{array}{r}6.6 \\
4.7 \\
15.3\end{array}$ & $\begin{array}{r}0.7 \\
17.3 \\
12.7\end{array}$ & $\begin{array}{r}1.0 \\
9.0 \\
11.7\end{array}$ & $\begin{array}{r}0.6 \\
6.0 \\
13.7\end{array}$ & $\begin{array}{r}5.0 \\
6.0 \\
12.3\end{array}$ \\
\hline
\end{tabular}

Table 6. Correlation coefficients of tests between seasonal patterns of biological and physical variables and seasonal changes in (A) density and (B) variety of the microflora at each level of Transect 1. For all correlations, d.f. = 14, except for those under 'Total no. of grazers', for which d.f. $=13$

\begin{tabular}{|c|c|c|c|c|c|c|c|}
\hline & Air temp. & Sea temp. & Rainfall & $\begin{array}{l}\text { No. of } \\
\text { windy } \\
\text { days }\end{array}$ & $\begin{array}{c}\% \text { of } \\
\text { possible } \\
\text { sunshine }\end{array}$ & $\begin{array}{l}\text { Proportion of } \\
\text { month with } \\
\text { heavy sweli }\end{array}$ & $\begin{array}{c}\text { Total } \\
\text { no. of } \\
\text { grazers }\end{array}$ \\
\hline \multicolumn{8}{|l|}{ A. Density } \\
\hline High level & $-078 \cdots$ & $-0.65 \cdots$ & $-0.37 \mathrm{~ns}$ & $0.24 \mathrm{~ns}$ & $0.43 \mathrm{~ns}$ & $-0.05 \mathrm{~ns}$ & $-0.27 \mathrm{~ns}$ \\
\hline Middle level & $-0.72 \cdots$ & $-0.43 \mathrm{~ns}$ & $-0.37 \mathrm{~ns}$ & $0.16 \mathrm{~ns}$ & $0.53^{\circ}$ & $-0.00 \mathrm{~ns}$ & $-0.11 \mathrm{~ns}$ \\
\hline Low level & $-0.91 \cdots$ & $-0.55^{\circ}$ & $-0.34 \mathrm{~ns}$ & $0.14 \mathrm{~ns}$ & $0.50 \mathrm{~ns}$ & $-0.05 \mathrm{~ns}$ & $-0.64^{\circ}$ \\
\hline Overall & $-0.86 \cdots$ & $-0.56^{\circ}$ & $-0.37 \mathrm{~ns}$ & $0.18 \mathrm{~ns}$ & $0.51^{\bullet}$ & $-0.04 \mathrm{~ns}$ & $-0.18 \mathrm{~ns}$ \\
\hline \multicolumn{8}{|l|}{ B. Variety } \\
\hline High level & $0.63 \cdots$ & $0.92 \cdots$ & $0.29 \mathrm{~ns}$ & $-0.58^{\circ}$ & $-0.32 \mathrm{~ns}$ & $0.42 \mathrm{~ns}$ & $0.61 \cdots$ \\
\hline Middle level & $0.50^{\circ}$ & $0.92 \cdots$ & $0.18 \mathrm{~ns}$ & $-0.63^{\circ}$ & $-0.30 \mathrm{~ns}$ & $0.33 \mathrm{~ns}$ & $0.19 \mathrm{~ns}$ \\
\hline Low level & $0.54^{*}$ & $0.93 \cdots$ & $0.25 \mathrm{~ns}$ & $-0.60^{\circ}$ & $-0.36 \mathrm{~ns}$ & $0.36 \mathrm{~ns}$ & $0.28 \mathrm{~ns}$ \\
\hline Overall & $0.57^{*}$ & $0.94^{\cdots}$ & $0.24 \mathrm{~ns}$ & $-0.61^{\circ}$ & $-0.33 \mathrm{~ns}$ & $0.37 \mathrm{~ns}$ & $0.55^{\circ}$ \\
\hline
\end{tabular}

The increased period of submersion at low levels is probably important in maintaining the vertical distribution of the microflora, which are more sensitive to such factors than macroscopic organisms (Castenholz 1963). Castenholz (1961b) reported that greater numbers of diatoms (and more species) were found at low levels on the shore and that only 1 or 2 species were found at high levels. The distribution of grazing gastropods probably also affects the vertical distribution of microflora (Castenholz 1961b). The density of such grazers (and, presumably, the grazing pressure) was significantly greater at high levels on the shore, where both density and variety of the microflora were least.

No clear pattern of vertical zonation was evident at Green Point, although some workers have reported zonation of diatoms (Aleem 1950, Hendey, in Round 1971). Diatoms were in evidence at all levels but were at greater density lower on the shore and their variety did not change with height on the shore. Anacystis sp., too, was found at all levels and exhibited no zonation, but spores, sporelings and microscopic green, red and brown algae were found only at the lowest levels and fungi and lichens were evident only at the high levels on the shore

\section{Temporal variations}

The density of microfloral cells varied from season to season, being greatest in winter and least in summer. The majority of this pattern was accounted for by seasonal changes in the density of all taxa except diatoms. Jernakoff (pers. comm.) has observed similar seasonal increases in abundance of green algal spores during winter, and Underwood (1981) observed such seasonal changes in the patterns of distribution of many macroalgae. In contrast, diatoms peaked in spring, perhaps in phase with a pulse of phytoplankton, known to occur seasonally in coastal waters (Hallegraeff 1981). Castenholz (1963) noted an increase in density of attached, but submerged, diatoms during summer, which he correlated with a bloom of planktonic species and with increased productivity brought about by increased light intensity. Such an explanation may also apply to the diatoms at Green Point. 
With the exception of diatoms, therefore, seasonal variations can be correlated with the increased physical harshness of the shore during summer. However, factors less direct than mortality due to physical extremes may be important. One such factor could be seasonal changes in the abundance or activity of grazing gastropods. The density of all grastropods, at all levels, dropped during winter and rose to a maximum in late summer.

The variety of the microfloral assemblage was greatest during the warmer months, not during winter. This may be attributable to 3 factors: (1) the density of Anacystis sp. spores and microscopic green, red and brown algae was greatly reduced during summer, thereby increasing the observed variety; (2) diatoms (as a group) increased both in number and variety during summer; and (3) gastropods increased in number and activity during summer, which may have resulted in a reduction in density of certain preferred species (MacLulich 1983). Even when the data were re-examined after disregarding the dominant blue-green algae Anacystis sp., these seasonal patterns in variety were still evident (as is suggested in Fig. 4A, B).

No previous studies have reported seasonal changes in variety of intertidal microalgae, so it is not possible to make comparison with other investigations. The seasonal changes in diversity of macroalgae at Green Point have, however, been recorded by Underwood (1981), and it is evident that they are completely out of phase with the microalgae.

Seasonal changes in physical conditions at Green Point may vary from year to year and, as a result, the seasonal differences in microflora described above may be unique to the period of the study. Similar investigations would obviously be desirable to provide information on how variable the microfloral assemblages are at different places and in different years. Nevertheless, it seems that the microfloral assemblages at Green Point undergo seasonal variations unlike those described for other systems in other parts of the world. Further experimental studies may reveal the causes of seasonal changes. Perhaps the comparatively mild, temperate climate in southeast Australia and the larger number of grazing gastropods on rock platforms in this region may be significant: this combination of factors has not been described in many other areas.

Acknowledgements. For their assistance with fieldwork, I thank P. Annetts, U. Kaly and I. MacLulich. I am indebted to P. Scanes for help in the laboratory and for his comments on the manuscript, and to A. Bartlett, caretaker of the Crommelin Biological Research Station of the University of Sydney. My gratitude goes to $\mathrm{Dr} \mathrm{A}_{\text {: }}$. Underwood for his advice with all aspects of the fieldwork, laboratory work, statistical analyses and preparation of the manuscript. The research described here formed part of the requirements for the degree of $\mathrm{M}$. Sc. in the Department of Zoology, University of Sydney.

\section{LITERATURE CITED}

Aleem, A. A. (1949). Distribution and ecology of marine littoral diatoms. Botaniska notiser 102: 414-440

Aleem, A. A. (1950). Distribution and ecology of British marine littoral diatoms. J. Ecol, 38: 75-106

Castenholz, R. W (1961a). The effect of grazing on marine littoral diatom populations. Ecology 42: 783-794

Castenholz, R. W. (1961b). An evaluation of a submerged glass method of estimating production of attached algae. Verh. int. Verein. Limnol. 14: 155-159

Castenholz, R.W (1963). An experimental study of the vertical distribution of littoral marine diatoms. Limnol. Oceanogr. 8: 450-462

Castenholz, R. W. (1967). Seasonal ecology of non-planktonic marine diatoms on the western coast of Norway. Sarsia 29: 237-256

Dakin, W. J. (1969). Australian seashores. Angus \& Robertson, Sydney

Dakin, W J., Bennett, I., Pope, E. (1948). A study of certain aspects of the ecology of the intertidal zone of the New South Wales coast. Aust. J. Sci. Res. Ser. B. 1: 176-230

Dayton, P. K. (1971). Competition, disturbance and community organisation: the provision and subsequent utilisation of space in a rocky intertidal community. Ecol. Monogr. 41: $351-389$

Dunkerley, G. M. (1979). The effect of grazing by herbivorous gastropods on microalgae. Honours thesis, Univ. of Sydney

Ghazzawi, F. M. (1933). The littoral diatoms of the Liverpool and Port Erin shores. J. mar. biol. Ass. U.K. 19: 165-176

Hallegraeff, G. M. (1981). Seasonal study of phytoplankton pigments and species at a coastal station off Sydney: importance of diatoms and the nanoplankton. Mar. Biol. 61. $107-118$

Hoagland, K. D., Roemer, S. C., Rosowski, J. R. (1982). Colonization and community structure of two periphyton assemblages, with emphasis on the diatoms (Bacillariopyceae). Am. J. Bot. 69: 188-213

Hopkins, J. T. (1964a). A study of the diatoms of the Ouse estuary, Sussex. II. The ecology of the mud flat diatom flora. J. mar. biol. Ass. U.K. 44: 333-341

Hopkins, J. T (1964b). A study of the diatoms of the Ouse estuary, Sussex. III. The seasonal variation in the littoral epiphyte flora and the shore plankton. J. mar biol. Ass. U.K. $44: 613-644$

Jeffrey, S. W., Carpenter, S. M. (1974). Seasonal succession of phytoplankton at a coastal station off Sydney. Aust. J. mar. Freshwat. Res. 25: 361-369

Lewis, J. R. (1964). Ecology of rocky shores. English Univ. Press, London

MacLulich, J. H. (1983). Aspects of the ecology of intertidal epilithic microflora at Green Point, New South Wales. M. Sc. thesis, Univ. of Sydney

MacLulich, J. H. (1986). Experimental evaluation of methods for sampling and assaying intertidal epilithic microalgae. Mar. Ecol. Prog. Ser 34:275-280

Mare, M. F. (1940). Plankton production of Plymouth and the mouth of the English Channel in 1939. J. mar. biol. Ass. U.K. 24: 461-482

McIntire, C. D., Overton, W. S. (1971). Distributional patterns in assemblages of attached diatoms from Yaquina estuary, Oregon. Ecology 52: 758-777

McIntire, C. D., Wulff, B. L. (1969). A laboratory method for the study of marine benthic diatoms. Limnol. Oceanogr. 14: $667-678$ 
Nicotri, M. E. (1974). Resource partitioning, grazing activities and influence on the microflora by intertidal limpets. Ph. D. thesis, Univ. of Washington, Seattle

Nicotri, M. E. (1977). Grazing effects of four marine intertidal herbivores on the microflora. Ecology 58: 1020-1032

Patrick, R. (1948). Factors affecting the distribution of diatoms. Bot. Rev. 14: 473-524

Patrick, R. (1964). Diatom communities in estuaries. In: Lauff, G. H. (ed.) Estuaries. Am. Ass. Advmt. Sci., New York, p. 311-315

Patrick, R. (1968). The structure of diatom communities in similar ecological conditions. Am. Nat. 102: 173-183

Patrick, R. (1972). Benthic communities in streams. Trans. Conn. Acad. Arts Sci. 44: 69-2-84

Patrick, R., Hohn, M. H., Wallace, J. H. (1954). A new method for determining the pattern of the diatom flora. Notulae Naturae 259: 1-12

Round, F. E. (1971). Benthic marine diatoms. Oceanogr. mar. Biol. A. Rev. 9: 83-139

Stephenson, T A., Stephenson, A. (1972). Life between tidemarks on rocky shores. W. H. Freeman, San Francisco
Underwood, A. J. (1976). Food competition between ageclasses in the intertidal neritacean Nerita atramentosa Reeve (Gastropoda: Prosobranchia) in S.E. Australia. J. exp. mar Biol. Ecol. 23: 145-154

Underwood, A. J. (1980). The effects of grazing by gastropods and physical factors on the upper limits of distribution of intertidal macroalgae. Oecologia (Berl.) 33: 185-208

Underwood, A. J. (1981). Structure of a rocky intertidal community in New South Wales: patterns of vertical distribution and seasonal changes. J. exp. mar. Biol. Ecol. 51: $57-85$

Underwood, A. J., Jernakoff, P. (1981). Interactions between algae and grazing gastropods in the structure of a lowshore algal community. Oecologia (Berl.) 48: 221-233

Underwood, A. J., Jernakoff, P. (1984). The effects of tidal height, wave exposure, seasonality and rock pools on grazing and distribution of intertidal macroalgae in New South Wales. J. exp. mar. Biol. Ecol. 75: 71-96

Wulff, B. L., McIntyre, C. D. (1972). Laboratory studies of assemblages of attached estuarine diatoms. Limnol. Oceanogr. 17: 200-214 